\title{
The Examination of the Relationship between the Secondary School Students' Habit of Reading and Their Reading Anxiety
}

\author{
Hilal Tonka (Corresponding author) \\ Abdurrahmangazi Secondary School, Erzurum, Turkey \\ E-mail: hila192.htt@gmail.com \\ Siddık Bakır \\ Turkish Education Department, K.K. Educational Faculty \\ Atatürk University, Turkey \\ E-mail: siddik.bakir@atauni.edu.tr
}

Received: May 6, 2020 Accepted: June 10, 2020 Published: June 21, 2020

doi:10.5296/jei.v6i1.16986 URL: https://doi.org/10.5296/jei.v6i1.16986

This study originates from a Master's thesis prepared by the first author under the guidance of the second author.

\begin{abstract}
This study aims to investigate the relationship between reading habits and reading anxiety of secondary school students. In this research, the relational survey model of quantitative research methods was used. The research population consists of students who study at primary schools in the Palandöken district of Erzurum province in the 2019-2020 academic year. The research sample consists of students studying at a secondary school in Palandöken district, including 358 student participants. The research data was collected using two scales. According to the findings, while the gender variable made a significant difference in the reading habits of the students, it did not make a significant difference in reading anxiety. In terms of other sub-problems, the variables of grade, watching television, and going to the library differ significantly in terms of students' reading habits and reading anxiety. While there was no significant difference in terms of the mother's educational level variable, there was a significant difference in favor of the students whose father graduated from secondary
\end{abstract}


education. In addition, it was found that there was a negative correlation between reading habits and reading anxiety of secondary school students, and that reading anxiety decreased when students' reading habits increased.

Keywords: Reading skills, Reading anxiety, Reading habits

\section{Introduction}

The most important features that distinguish the human being as a part of nature from other beings are that he has the ability to think and speak and the knowledge he has obtained with them (Mert, Alyılmaz, Bay, \& Akbaba, 2009). One of the main characteristics that make an individual become a social creature is language skills. Through language, the individual interacts with the environment, and language contributes to the integration of the individual with the outside world (Er, Biçer, \& Bozkırlı, 2012, p. 52). The language also has a systematic and complex structure. Within this structure, each language comes up with its own unique rules (Biçer, Çoban, \& Bakır, 2014, p. 126). Language acquisition and education of the individual develops in a given time frame. Language acquisition begins in preschool as a result of the child's interaction with their family and immediate environment (Aly1lmaz, 2010, p. 729). Initially, reading, which begins with a recognition of symbols and is an effective language skill, is an important need that people need to sustain throughout their lives. In the later stage of the process, symbols in mind are evaluated and interpreted. The understanding step is not only about definition but also includes the evaluation and interpretation stages (Bamberger, 1990). This mental process becomes a habit with regular repetitions, and a process of interpretation begins beyond seeing symbols.

What is important in the process of reading is not the perception of letters, but the meaning of the letters. According to Harris and Sipay (1990), reading is the interpretation of shapes in mind. In other words, reading is "comprehension" (as cited in Balc1, 2009).

Reading, which is one of the language skills, is a useful skill that needs to be given importance as it contributes to the development of other skill areas. It is an essential means of acquiring knowledge within language skills. It is the interpretation and meaning of the signs perceived by the eye by the brain. Reading activity contributes to the development of questioning, critique, research, evaluation, and interpretation skills of individuals (MEB, 2006). As a lifelong source of learning (Tekin, 1980), it becomes a habit by repeating. Considering that this skill which supports the development of mental activities (Balc1, 2009) also provides the social and cultural development of individuals, individuals should continue their reading habits throughout their lives and should acquire this skill at an early age.

Reading skills, which becomes a habit at an early age, come after basic literacy. The individual will continue this activity if $\mathrm{s} / \mathrm{he}$ turns the reading habit into a routine that $\mathrm{s} / \mathrm{he}$ will enjoy and gains a critical perspective. In other words, the process of reading habit, which follows the basic reading skill, is the process of internalizing the individual's reading and making this action habitual by being motivated to read (Gürcan, 1996).

The reading habit needs to be gained at an early age and becomes a systematic and programmatic routine during the life of education. Individuals who make a habit of reading 
will develop reading comprehension, interpretation, evaluation skills, and the ability to use language. Reading is an act that supports and accelerates the thinking system. In addition, individuals have a free and critical thinking structure by reading books, which is a necessity of contemporary life. They can also express themselves more accurately and effectively with the good speech skills they have gained.

Continuing reading habit by making it an enjoyable task is important in the development of students' reading and writing skills and creative intelligence (Tanju, 2010). Since reading habit develops many skill areas with itself, it is vital to gain and acquire this habit at an early age. The knowledge accumulation of individuals who has reading habit increases, their skills of using language improve, and they can use their thought systems more effectively.

Assessments about why students do not read should be conducted, individual factors that take students away from reading skills should be determined, and anxiety conditions should be taken under control in these frameworks in order for the students to gain reading habits.

Societies need individuals who continuously renew themselves, maintain their values, and follow the current developments to be able to develop, compete internationally, and carry all material and spiritual accumulation to the next generations (Küçükoğlu, Taşgın, \& Saadnie, 2014, p. 396). Therefore, in today's conditions, individuals have to learn continuously. Reading, comprehension, interpretation, critical thinking, expressing oneself appropriately and effectively, and using Turkish according to its rules are all these skills that can be developed by reading books. In institutions where the reading habit is systematically tried to be taught, students can achieve the habit of reading books more quickly if the reasons why they avoid reading, why they do not like reading, and the factors that will cause anxiety are determined.

Students can acquire the love of language thanks to their reading habits and move the language with cultural treasures to future generations in a safe manner. It is directly proportional to the reading habits that students acquire and use skills that are present in all areas of our lives, such as understanding, explaining, listening, speaking, and writing.

\subsection{Purpose of the Research}

The aim of this research is to establish the relationship between reading habits and reading anxiety of secondary school students. For this purpose, the sub-problems of the study are as follows:

1. Do secondary school students' reading habits and reading anxieties differ by gender?

2. Do secondary school students' reading habits and reading anxieties differ by grade?

3. Do secondary school students' reading habits and reading anxieties differ by the mother's educational level?

4. Do secondary school students' reading habits and reading anxieties differ by the father's educational level?

5. Do secondary school students' reading habits and reading anxieties differ by going to the 
library?

6. Do secondary school students' reading habits and reading anxieties differ by the frequency of watching television?

\section{Method}

\subsection{Research Model}

In this research, the relational survey model of quantitative research methods was used. The model that aims to determine the variation or correlation between two or more variables is named the relational survey model. Survey models have been expressed as approaches in which a situation that exists in the past and present, the event, person, or object that is the subject of research is attempted to be defined in its terms. However, in these models, there is no effort to change the research and its elements in any way (Karasar, 2013).

\subsection{Population and Sample}

The research population consists of students who continue their education in secondary schools in the Palandöken district of Erzurum in the academic year of 2019-2020. The research sampling involves the students of a secondary school in Palandöken district, which is determined according to the purposive sampling method. The students included in the study consist of all grade levels and both genders.

\subsection{Data Collection Tools}

In this study, the "Secondary School Reading Habit Scale" developed by Tok, Küçük, and Kırmacı (2015) and the "Reading Anxiety Scale" developed by Çeliktürk and Yamaç (2015) were used. A personal information form was added to the scales by the researcher, and various information about the students was collected in this way.

There are 15 items with a 5-point Likert-type in the "Secondary School Reading Habit Scale". Students selected their opinions for each item by preferring one of the phrases "strongly disagree (1), disagree (2), slightly agree (3), agree (4), and strongly agree (5)". The Cronbach alpha reliability coefficient of the scale is 0.89 .

There are 29 items with 5-point Likert-type in the "Reading Anxiety Scale" to determine students' reading anxiety levels. Students reflected their views for each item by marking one of the options "never (1), rarely (2), sometimes (3), often (4), and always (5)". The Cronbach alpha reliability coefficient of the scale is 0.95 .

\subsection{Process and Implementation}

The "Secondary School Reading Habit Scale" and the "Reading Anxiety Scale" were used in this study. A personal information form was added to the scales. Permission was obtained from the Provincial Directorate of National Education to implement the scale in schools. The importance of the scale in the implementation process was explained by the researcher, and students were asked to fill it out on a voluntary basis. The implementation was completed in a total of 40 minutes of class hours by filling out the scales and personal information form at 
the school and making the necessary explanations.

\subsection{Data Analysis}

Prior to data analysis, the data was checked to see if it was suitable for normal distribution. Mean and median values of the data from each variable were reviewed, and the normality tests for each variable (Kolmogorov Smirnov/Shapiro Wilk) were conducted. The kurtosis and skewness coefficients were examined separately. Then the Q-Q plot and box plot for each variable were examined. As a result of analyses and graphical analyses, it was concluded that the data was not normally distributed. It was also determined to use non-parametric tests in the data because the number of participants in some variables is less than 30 .

Mann Whitney U test was used to detect the difference between two categorical variables and a continuous variable, the Kruskal Wallis test was used to identify a significant difference between a variable with more than two categories and a continuous variable, and the Spearman's Rank Correlation Coefficient was used to determine the relationship between two continuous variables. In cases where significant differences were found in the Kruskal Wallis test, the new significance value was calculated with the Bonferroni correction, and interpretations were made according to this new value.

\section{Results}

358 students took part in the research. 181 participants of them are school girls, 177 participants of them are school boys. The findings from the research results are given in the following tables:

Descriptive statistics related to the average scores of secondary school students on reading habits are given in Table 1. 
Table 1. Mean and standard deviation scores of secondary school students related to the reading habit scale items

\begin{tabular}{|c|c|c|c|}
\hline & Items & $\bar{X}$ & sd \\
\hline \multirow{7}{*}{$\begin{array}{l}\text { Reflection of } \\
\text { Books to Skills }\end{array}$} & "I can read fluently." & 3.65 & 1.25 \\
\hline & "I have a high level of general culture level because I read books." & 3.35 & 1.24 \\
\hline & "My imagination and creativity improved because I read books." & 3.70 & 1.31 \\
\hline & "I try to improve my vocabulary." & 3.58 & 1.34 \\
\hline & "I pay attention to the words I choose when writing or speaking." & 3.76 & 1.33 \\
\hline & $\begin{array}{l}\text { "I write the structure and content of my sentences properly while } \\
\text { writing." }\end{array}$ & 3.50 & 1.33 \\
\hline & "I can comfortably write a composition." & 3.27 & 1.29 \\
\hline \multirow{5}{*}{$\begin{array}{l}\text { Relationship } \\
\text { with the Book }\end{array}$} & "I like to be given a book as a gift." & 3.87 & 1.38 \\
\hline & "I try to create my library." & 3.37 & 1.37 \\
\hline & "I carry a book with me." & 3.49 & 1.42 \\
\hline & "I read when there is no teacher in class." & 3.55 & 1.28 \\
\hline & "I take special time to read." & 3.48 & 1.29 \\
\hline \multirow{3}{*}{$\begin{array}{l}\text { Orientation to } \\
\text { Expression Based } \\
\text { on Books }\end{array}$} & "I do writing essays in the genres of story, poetry, essays, etc." & 2.99 & 1.29 \\
\hline & "I summarize the books I read." & 3.40 & 1.32 \\
\hline & "I quote many books in my speeches." & 3.11 & 1.33 \\
\hline
\end{tabular}

Table 1 indicates that while the most preferred item in the "Reflection of Books to Skills" sub-dimension is "I pay attention to the words I choose when writing or speaking $(\bar{X}=$ 3.76)," the least selected item is "I can comfortably write a composition ( $\bar{X}=3.27)$." The most preferred item in the "Relationship with the Book" sub-dimension is "I like to be given a book as a gift $(\bar{X}=3.87)$," while the least selected item is "I try to create my library $(\bar{X}=$ 3.37)." In the "Orientation to Expression Based on Books" sub-dimension, the most preferred item is "I summarize the books I read $(\bar{X}=3.40)$," while the least selected item is "I do writing essays in the genres of story, poetry, essays, etc. $(\bar{X}=2.99)$." This result suggests that secondary school students generally express a positive opinion about the items of the scale regarding their reading habits.

Descriptive statistics for the sub-dimension and overall mean of the opinions of secondary school students on their reading habits are given in Table 2. 
Table 2. Descriptive statistics of the sub-dimension and overall mean scores of secondary school students' opinions on reading habit

\begin{tabular}{|l|l|l|l|}
\hline Dimensions & $\bar{X}$ & sd & Opinion \\
\hline Reflection of Books to Skills & 3.55 & .91 & Agree \\
\hline Relationship with the Book & 3.55 & .96 & Agree \\
\hline Orientation to Expression Based on Books & 3.17 & .94 & Slightly Agree \\
\hline Total & 3.47 & .83 & Agree \\
\hline
\end{tabular}

When the overall mean scores of secondary school students about their reading habits regarding sub-dimensions and the arithmetic averages in the overall total are examined, the overall opinions in the sub-dimensions of "Reflection of Books to Skills" and "Relationship with the Book" are "Agree," while it is "Slightly Agree" in the "Orientation to Expression Based on Books" sub-dimension.

Descriptive statistics of the secondary school students' mean scores for reading anxiety scale are given in Table 3 .

Table 3. Mean and standard deviation scores of the secondary school students' reading anxiety scale items

\begin{tabular}{|c|c|c|c|c|}
\hline \multicolumn{2}{|c|}{ Items } & \multirow{2}{*}{$\frac{\bar{X}}{2.08}$} & \multirow{2}{*}{$\frac{\mathrm{sd}}{1.42}$} & \\
\hline 1 & "I panic when I read in class." & & & \multirow{12}{*}{ 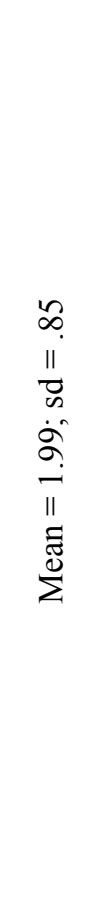 } \\
\hline 2 & "The thought that I will read worse than my friends makes me nervous." & 2.25 & 1.39 & \\
\hline 3 & $\begin{array}{l}\text { "The thought of me not being able to adjust my tone when I read makes me } \\
\text { nervous." }\end{array}$ & 2.08 & 1.35 & \\
\hline 4 & "I feel anxious in reading classes." & 1.90 & 1.28 & \\
\hline 5 & "I get nervous when I am required to read a text." & 1.96 & 1.31 & \\
\hline 6 & "I get nervous before I start reading a text." & 2.02 & 1.22 & \\
\hline 7 & "When I read aloud in class, my voice trembles because I fear doing wrong." & 2.14 & 1.38 & \\
\hline 8 & "I think my reading in the classroom environment will not be liked." & 2.16 & 1.31 & \\
\hline 9 & "I have trouble focusing my attention when reading a text." & 1.90 & 1.24 & \\
\hline 10 & "I panic when I read through a limited amount of time." & 2.15 & 1.39 & \\
\hline 11 & "I do not take the time to read because reading worries me." & 1.86 & 1.26 & \\
\hline 12 & "My palms sweat as I read a text." & 2.14 & 1.41 & \\
\hline 13 & "My heart beats when the teacher makes me read aloud in class." & 2.08 & 1.42 & $\ddot{\sigma} \overline{\text { ğ }}$ \\
\hline
\end{tabular}




\begin{tabular}{|c|c|c|c|}
\hline 14 & "When I read aloud in class, my knees tremble with excitement." & 1.99 & 1.33 \\
\hline 15 & "The thought of reading an entire text bothers me." & 1.70 & 1.21 \\
\hline 16 & "I make myself a problem reading a text." & 1.67 & 1.15 \\
\hline 17 & "Whenever I read a text, my head/stomach starts to ache." & 1.63 & 1.17 \\
\hline 18 & "I avoid reading because I cannot read fluently." & 1.63 & 1.17 \\
\hline 19 & "After reading in the classroom environment, I worry if I can read well." & 2.31 & 1.41 \\
\hline 20 & "I feel unsuccessful after reading a text." & 1.91 & 1.31 \\
\hline 21 & $\begin{array}{l}\text { "The thought of not being able to adjust my breath while reading makes me } \\
\text { nervous." }\end{array}$ & 1.95 & 1.24 \\
\hline 22 & "I get excited when I read aloud in a classroom setting." & 2.44 & 1.48 \\
\hline 23 & "The thought that I would get bad grades from my readings bothers me." & 2.40 & 1.44 \\
\hline 24 & "I hesitate to read aloud in a classroom setting." & 1.79 & 1.26 \\
\hline 25 & $\begin{array}{l}\text { "The thought of my reading not being understood by others makes me } \\
\text { nervous." }\end{array}$ & 2.18 & 1.37 \\
\hline 26 & $\begin{array}{l}\text { "When I read a text, I cannot understand what I am reading out of } \\
\text { excitement." }\end{array}$ & 2.06 & 1.31 \\
\hline 27 & "Whenever I pick up a text to read, I lose the ability to think." & 1.71 & 1.22 \\
\hline 28 & "I get nervous even when I reread a text." & 1.74 & 1.24 \\
\hline 29 & "I get worried when I read texts I have not read before." & & \\
\hline
\end{tabular}

Table 3 shows that the most preferred item in the reading anxiety scale is "I get excited when I read aloud in a classroom setting $(\bar{X}=2.44)$," while the least selected items are "Whenever I read a text, my head/stomach starts to ache $(\bar{X}=1.63)$ " and "I avoid reading because I cannot read fluently $(\bar{X}=1.63)$."

Whether secondary school students' reading habits and reading anxieties differ according to gender, and the data did not show normal distribution, they were analyzed with Mann Whitney U Test and the results are presented in Table 4. 
Table 4. Differentiation of Secondary School Students' Reading Habits and Reading Anxiety by Gender Variable

\begin{tabular}{|l|l|l|l|l|l|l|l|}
\hline & Gender & $\mathrm{N}$ & Mean Rank & Sum of Ranks & U & Z & $\mathrm{p}$ \\
\hline \multirow{3}{*}{ Reading Habit } & Girl & 181 & 195.67 & 35415.50 & \multirow{2}{*}{13092.50} & -2.990 & \multirow{2}{*}{.003} \\
\cline { 2 - 6 } & Boy & 177 & 162.97 & 28845.50 & & & \\
\hline \multirow{3}{*}{ Reading Anxiety } & Girl & 181 & 172.74 & 31266.00 & \multirow{2}{*}{14795.00} & -1.250 & .211 \\
\cline { 2 - 8 } & Boy & 177 & 186.41 & 32995.00 & & & \\
\hline
\end{tabular}

Based on the figures in Table 4, there was a significant difference in secondary school students' reading habits with reading anxiety by the gender variable $[\mathrm{U}=13092.5, \mathrm{z}=-2.990$, $\mathrm{p}<.05]$, while there is no significant differentiation in their reading anxiety $[\mathrm{U}=14795, \mathrm{z}=$ $-1.250, \mathrm{p}>.05]$. When the reading habits of the middle school students were examined with the mean ranks of the girl students (195.67) and the mean ranks of the boy students (162.97), it was concluded that there was a significant difference in favor of the girl students.

Whether secondary school students' reading habits and reading anxieties differ according to age variable, because the data did not show normal distribution, they were analyzed with Kruskal Wallis Test and the results are presented in Table 5.

Table 5. Differentiation of secondary school students' reading habits and reading anxiety by age variable

\begin{tabular}{|c|c|c|c|c|c|c|}
\hline & Age & $\mathrm{N}$ & Mean Rank & $\mathrm{df}$ & $x^{2}$ & $\mathrm{p}$ \\
\hline \multirow{5}{*}{ Reading Habit } & 10 & 33 & 180.73 & \multirow{5}{*}{4} & \multirow{5}{*}{2.077} & \multirow{5}{*}{.722} \\
\hline & 11 & 103 & 182.76 & & & \\
\hline & 12 & 101 & 171.11 & & & \\
\hline & 13 & 89 & 189.40 & & & \\
\hline & 14 & 32 & 166.69 & & & \\
\hline \multirow{5}{*}{ Reading Anxiety } & 10 & 33 & 165.39 & \multirow{5}{*}{4} & \multirow{5}{*}{1.602} & \multirow{5}{*}{.808} \\
\hline & 11 & 103 & 181.34 & & & \\
\hline & 12 & 101 & 187.92 & & & \\
\hline & 13 & 89 & 175.75 & & & \\
\hline & 14 & 32 & 171.98 & & & \\
\hline
\end{tabular}

The Kruskal Wallis test was performed to test whether secondary school students' reading 


\section{Macrothink}

habits and reading anxiety differ significantly by the age variable and it was found that there were no significant differences between the mean ranks of the groups $\left[X^{2}\right.$ Reading Habit (4) $=2.077$, $\left.\mathrm{p}>.05 ; X_{\text {Reading Anxiety (4) }}^{2}=1.602, \mathrm{p}>.05\right]$.

Whether the reading habits and reading anxieties of secondary school students' differ according to the class variable, since the data did not show normal distribution, they were analyzed with the Kruskal Wallis Test and the results are presented in Table 6.

Table 6. Differentiation of secondary school students' reading habits and reading anxiety by grade variable

\begin{tabular}{|c|c|c|c|c|c|c|}
\hline & Grade & $\mathrm{N}$ & Mean Rank & df & $x^{2}$ & $\mathrm{p}$ \\
\hline \multirow{4}{*}{ Reading Habit } & $5^{\text {th }}$ grade & 90 & 171.44 & \multirow{4}{*}{3} & \multirow{4}{*}{5.859} & \multirow{4}{*}{.119} \\
\hline & $6^{\text {th }}$ grade & 94 & 175.34 & & & \\
\hline & $7^{\text {th }}$ grade & 71 & 165.90 & & & \\
\hline & $8^{\text {th }}$ grade & 103 & 199.72 & & & \\
\hline \multirow{4}{*}{ Reading Anxiety } & $5^{\text {th }}$ grade & 90 & 189.09 & \multirow{4}{*}{3} & \multirow{4}{*}{4.118} & \multirow{4}{*}{.249} \\
\hline & $6^{\text {th }}$ grade & 94 & 184.65 & & & \\
\hline & $7^{\text {th }}$ grade & 71 & 185.55 & & & \\
\hline & $8^{\text {th }}$ grade & 103 & 162.24 & & & \\
\hline
\end{tabular}

The Kruskal Wallis test was performed to test whether the reading habits and reading anxiety of the secondary school students differ significantly by the grade variable and it was seen that there were no significant differences between the mean ranks of the groups $\left[X^{2}{ }_{\text {Reading Habit(3) }}=\right.$ $\left.5.859, \mathrm{p}>.05 ; X_{\text {Reading Anxiety (3) }}^{2}=4.118, \mathrm{p}>.05\right]$.

Whether the reading habits and reading anxieties of secondary school students' differ significantly according to the mother education status variable was analyzed with the Kruskal Wallis Test and the results are presented in Table 7. 


\section{Macrothink}

Table 7. Differentiation of secondary school students' reading habits and reading anxiety by mother's educational level

\begin{tabular}{|c|c|c|c|c|c|c|}
\hline & Mother's Education Level & $\mathrm{N}$ & Mean Rank & df & $x^{2}$ & $\mathrm{p}$ \\
\hline \multirow{5}{*}{ Reading Habit } & Illiterate & 132 & 160.97 & \multirow{5}{*}{5} & \multirow{5}{*}{7.937} & \multirow{5}{*}{.094} \\
\hline & Primary School & 164 & 191.57 & & & \\
\hline & Secondary School & 44 & 187.75 & & & \\
\hline & High School & 15 & 196.90 & & & \\
\hline & University & 3 & 127.17 & & & \\
\hline \multirow{5}{*}{ Reading Anxiety } & Illiterate & 132 & 196.13 & \multirow{5}{*}{4} & \multirow{5}{*}{9.270} & \multirow{5}{*}{.055} \\
\hline & Primary School & 164 & 166.34 & & & \\
\hline & Secondary School & 44 & 171.59 & & & \\
\hline & High School & 15 & 179.83 & & & \\
\hline & University & 3 & 282.00 & & & \\
\hline
\end{tabular}

The Kruskal Wallis test was conducted to test whether the reading habits and reading anxiety of the secondary school students differ significantly by mother's educational level, and it was found out that there were no significant differences between the mean ranks of the groups $\left[X^{2}\right.$ Reading Habit (4) $\left.=7.937, \mathrm{p}>.05 ; X_{\text {Reading Anxiety (4) }}^{2}=9.270, \mathrm{p}>.05\right]$.

Whether the reading habits and reading anxieties of secondary school students' differ according to the father's educational status variable was analyzed with the Kruskal Wallis Test since the data did not show normal distribution and the results are presented in Table 8 . 


\section{Ml Macrothink}

Table 8 . Differentiation of secondary school students' reading habits and reading anxiety by father's educational level

\begin{tabular}{|c|c|c|c|c|c|c|c|}
\hline & Father's Education Level & $\mathrm{N}$ & Mean Rank & $\mathrm{df}$ & $x^{2}$ & $\mathrm{p}$ & Difference \\
\hline \multirow{5}{*}{ Reading Habit } & 1. Illiterate & 28 & 145.73 & \multirow{5}{*}{4} & \multirow{5}{*}{5.777} & \multirow{5}{*}{.216} & \\
\hline & 2. Primary School & 157 & 175.11 & & & & \\
\hline & 3. Secondary School & 101 & 191.42 & & & & \\
\hline & 4. High School & 54 & 192.27 & & & & \\
\hline & 5. University & 18 & 165.11 & & & & \\
\hline \multirow{5}{*}{ Reading Anxiety } & 1. Illiterate & 28 & 233.84 & \multirow{5}{*}{4} & \multirow{5}{*}{11.698} & \multirow{5}{*}{.020} & \multirow{5}{*}{$\begin{array}{l}1>3 \\
1>4\end{array}$} \\
\hline & 2. Primary School & 157 & 185.69 & & & & \\
\hline & 3. Secondary School & 101 & 163.60 & & & & \\
\hline & 4. High School & 54 & 167.27 & & & & \\
\hline & 5. University & 18 & 166.92 & & & & \\
\hline
\end{tabular}

The Kruskal Wallis test was carried out to test whether the reading habits and reading anxiety of the secondary school students differ significantly by father's educational level, and it was found out that while there were no significant differences between the mean ranks of the groups in relation to reading habit $\left[X^{2}\right.$ Reading Habit (4) $\left.=5.777, \mathrm{p}>.05\right]$, there was a significant difference in terms of reading anxiety $\left[X^{2}{ }_{\text {Reading Anxiety (4) }}=11.698, \mathrm{p}<.05\right]$.

The significant difference in reading anxiety among secondary school students in relation to the father's educational status variable was analyzed by the Mann Whitney U test. The new significance value was calculated as 0.005 with the Bonferroni correction. In this case, it is understood that there is a significant difference in favor of illiterate ones between students whose father's educational status is illiterate and those whose father's educational status is secondary school graduate and in favor of illiterate ones between illiterate students whose father's education level is illiterate and those whose father's education level is high school graduate. Since the increase in reading anxiety mean scores is negatively interpreted, this situation can be interpreted as the ones whose father's education level is secondary school graduate and high school graduates have less reading anxiety.

Whether the reading habits of middle school students' and reading anxieties differ according to the variable of going to the library, the data were analyzed with Mann Whitney U Test and the results are presented in Table 9. 
Table 9. Differentiation of secondary school students' reading habits and reading anxiety by going to library

\begin{tabular}{|l|l|l|l|l|l|l|l|}
\hline \multicolumn{2}{|l|}{ Going to Library } & N & Mean Rank & Sum of Ranks & U & Z & p \\
\hline \multirow{3}{*}{ Reading Habit } & Yes & 137 & 205.92 & 28211.5 & \multirow{2}{*}{11518.5} & -3.805 & .000 \\
\cline { 2 - 9 } & No & 221 & 163.12 & 36049.5 & & & \\
\hline \multirow{3}{*}{ Reading Anxiety } & Yes & 137 & 159.34 & 21829.5 & \multirow{2}{*}{12376.5} & -2.904 & .004 \\
\cline { 2 - 9 } & No & 221 & 192.00 & 42431.5 & & & \\
\hline
\end{tabular}

Table 9 shows that there is a significant difference in reading habits and reading anxiety in secondary school students' reading habits and reading anxiety by going to the library variable $\left[\mathrm{U}_{\text {Reading Habit }}=11518.5, \mathrm{z}=-3.805, \mathrm{p}<.05 ; \mathrm{U}_{\text {Reading Anxiety }}=12376.5, \mathrm{z}=-2.904, \mathrm{p}<.05\right]$. When the mean ranks of the differentiation of the secondary school students' reading habits by the variable of going to library are examined, there is a significant difference between the mean ranks of students who go to the library (205.92) and the mean ranks of students who do not go to the library (163.12) in favor of the students who go to the library. When the mean ranks of the differentiation of the secondary school students' reading anxiety by the variable of going to library are examined, it is understood that there is a significant difference in favor of the students who go to the library between the mean ranks of students who go to the library (159.34) and the mean ranks of students who do not go to the library (192.00).

Whether the reading habits and reading anxieties of secondary school students differ according to the frequency of television viewing varies, the data were analyzed with the Kruskal Wallis Test and the results are presented in Table 10.

Table 10. Differentiation of secondary school students' reading habits and reading anxiety by the frequency of watching television

\begin{tabular}{|c|c|c|c|c|c|c|c|}
\hline & Frequency of Watching TV & $\mathrm{N}$ & Mean Rank & $\mathrm{df}$ & $x^{2}$ & $\mathrm{p}$ & Difference \\
\hline \multirow{3}{*}{ Reading Habit } & 1. 1 hour a day & 166 & 193.17 & \multirow{3}{*}{2} & \multirow{3}{*}{23.223} & \multirow{3}{*}{.000} & \multirow{3}{*}{$\begin{array}{l}1>3 \\
2>3\end{array}$} \\
\hline & 2. 2 hours a day & 99 & 198.23 & & & & \\
\hline & 3. More than 2 hours a day & 93 & 135.16 & & & & \\
\hline \multirow{3}{*}{ Reading Anxiety } & 1. 1 hour a day & 166 & 160.53 & \multirow{3}{*}{2} & \multirow{3}{*}{11.177} & \multirow{3}{*}{.004} & \multirow{3}{*}{$1>2$} \\
\hline & 2. 2 hours a day & 99 & 189.55 & & & & \\
\hline & 3. More than 2 hours a day & 93 & 202.66 & & & & \\
\hline
\end{tabular}

The Kruskal Wallis test was performed to test whether the reading habits and reading anxiety of secondary school students differed by the frequency of watching television and it was 
found out that there was a significant difference in reading habits and reading anxiety among the group's mean ranks $\left[X^{2}{ }_{\text {Reading Habit (2) }}=23.223, \mathrm{p}<.05 ; X^{2}{ }_{\text {Reading Anxiety (2) }}=11.177, \mathrm{p}<.05\right]$. Mann Whitney $U$ test was used to determine the significant difference among which groups and in favor of which group regarding secondary school students' reading habits and reading anxiety by the frequency of watching television. The new significance value was calculated as 0.016 with Bonferroni correction. In this case, there is a significant difference in terms of secondary school students' reading habits in favor of the students who watch television for 1 hour every day between students who watch television for 1 hour every day and students who watch television for more than 2 hours every day. There is a significant difference in terms of secondary school students' reading habits in favor of the students who watch television for 2 hours every day between students who watch television for 2 hours every day and students who watch television for more than 2 hours every day. With regard to the reading anxiety of secondary school students, there is a significant difference in favor of students who watch television for 1 hour every day between those who watch television for 1 hour every day and those who watch television for 2 hours every day.

The data on the Spearman Sequence Difference Correlation Coefficient made to determine the relationship between middle school students' reading habits and reading anxieties are presented in Table 11.

Table 11. Relationship between secondary school students' reading habits and reading anxiety

\begin{tabular}{|l|l|l|l|}
\hline & & Reading Habit & Reading Anxiety \\
\hline \multirow{2}{*}{ Reading Habit } & Correlation & & $-.306^{* *}$ \\
\cline { 2 - 4 } & $\mathrm{P}$ & & .000 \\
\hline \multirow{2}{*}{ Reading Anxiety } & Correlation & $-.306^{* *}$ & \\
\cline { 2 - 5 } & $\mathrm{P}$ & .000 & \\
\hline
\end{tabular}

When the table is examined, it is concluded that there is a negative correlation between reading habits and reading anxiety of secondary school students $[\mathrm{r}=-.306, \mathrm{n}=358, \mathrm{p}<.01]$. This result suggests that reading anxiety decreases with the increase in the reading habits of students.

\section{Conclusion and Discussion}

Based on the findings of this study, which was conducted to determine the relationship between reading habits and reading anxiety of secondary school students, it was concluded that there was a negative significant relationship between reading habits and reading anxiety of secondary school students. This result also indicates that reading anxiety decreases with the increase in the reading habits of students. When the literature is reviewed, it is seen that there are studies consistent with the findings of this research. 


\section{Mll Macrothink}

Journal of Educational Issues

ISSN 2377-2263

2020, Vol. 6, No. 1

The results of this research are in line with the findings of Yamaç and Sezgin's (2018) research results, indicating that reading anxiety affects reading habits negatively. Y1ldiz and Ceyhan (2016) stated that reading skills, which is one of the language skills, is a learned skill and pointed out the importance of identifying anxiety, determining anxiety level, and determining the influencing variables. Baki (2017) determined that reading anxiety and reading attitude directly and significantly affect reading habit, and concluded that reading habit was indirectly affected by reading anxiety and directly by reading attitude. Besides them, while Mori (2004) stated that there is a significant relation between positive attitude towards reading and reading frequency as behaviour (habit), MacIntyre and Gardner (1991), stated that reading anxiety decreases depending on the development of reading skills. In another study by Grills-Taquechel, Vaughn, and Stuebing (2012) it was stated that anxiety indicators in reading fluency are negative precursors.

In terms of the gender variable, which is the first sub-problem of the study, it is observed that there is a significant difference in reading habits and reading anxiety among secondary school students in reading habits compared to the gender variable, and there is no significant difference in reading anxiety. In the review of the literature, there are also different studies that reveal that the gender variable constitutes significant differences. For example, Worrell, Roth, David, and Gabelko (2006), found out in their study that there are higher significant scores on behalf of girls in terms of reading attitudes in three class levels. Schwabe, McElvany, and Trendtel (2015), showed in their study named "The School Age Gender Gap in Reading Achievement: Examining the influences of Item Format and Intrinsic Reading Motivation" that girls have specific advantages in structured answer items than boys who have same reading skills. In their research titled "Reading Habits of the Secondary School Students $(6,7,8$. grades) (sample of Kayseri)", Topçu (2005) stated that the gender factor had a significant difference in reading habits as a result of his analyses. In Keleş's (2006) research, a significant difference was found in favor of female students. Güngör (2009) highlighted in their research that female students read more books. Davarcı (2013), who obtained similar results, concluded that female students' reading habits are higher than male students. Addressing the reading motivations of primary school students in terms of some variables, Ataş (2015) found that the percentage of female students in terms of value given to reading was higher than that of male students. When the literature is reviewed, it is also seen that there are studies that acquired different results. Soysal (2014) found out in their study, which examined students' reading comprehension levels in terms of different variables, that gender factor did not result in a significant difference in reading comprehension level. Çetinkaya (2004) also emphasized in their study titled "The Reading Habits of 8th Class Primary School Students in Afyon Centre" that gender is significantly effective in the number of books read in the past year.

Considering the results of the second sub-problem of the research, whether students' reading habits and reading anxiety change according to the grade variable, the analyses indicate that there is no significant difference in terms of the grade variable. In his study, Karahan (2015) determined that 5th and 6th-grade students' attitudes towards reading differ significantly according to the grade variable. According to Ataş (2015), the importance given to reading is 
influenced by the grade variable. It was determined that the importance given by the students at the 2nd and 3rd-grade levels was higher than the students at the 4th-grade level. In their research, reader self-perceptions are also higher in favor of 2nd and 3rd-grade students compared to 4th-grade students. Rains (1993), concluded in his study that reading attitudes of students studying in 5thand 6th grades are lower than the ones studying in the lower grades.

Dilbaz (2019) compared students' levels of reader self-perception in terms of grade variable and concluded that the group with the lowest level of self-perception was students at 8th graders, while students in grade 5 and grade 6 had high levels of reader self-perception.

In the third sub-problem of the study, it was determined whether the reading habits and reading anxiety of secondary school students differ by the mother's educational level variable, and there was no significant difference between the mean ranks of the groups.

In the fourth sub-problem of the study, it was tested whether the reading habits and reading anxiety of secondary school students differ by father's educational level variable. There is a significant difference in favor of illiterate ones between students whose father's educational status is illiterate and those whose father's educational status is secondary school graduate and in favor of illiterate ones between illiterate students whose father's education level is illiterate and those whose father's education level is high school graduate. Since the increase in reading anxiety scores is negatively interpreted, it was concluded that students whose fathers are secondary school graduate and high school graduate suffered less reading anxiety. In their study of "Is there a significant difference between the reading habits of 5th-grade primary school students by the educational level of their parents?" Güngör (2009) determined that the effect level of the mother's education level on the students' reading habits was higher than that of the father. Davarc1 (2013) noted in their study that as parents' levels of education increased, there was a decrease in the percentage of students preferring to read books in their spare time. Soysal (2014) found that the father's educational status did not cause a significant difference in the level of reading comprehension. In the same research, it was determined that the mother's education level caused a significant difference. Duran's (2018) study found significant differences in students' reading habits in favor of those with higher parental educational level. Similarly, Gül (2019) concluded that the parental educational level did not constitute a significant difference in their study. Karademir (2018) revealed that the education level of the mother affects the reading habits of the students higher than the father. Dilbaz (2019) noted in their study that increasing mother's education levels also led to an increase in students' reading attitudes. The remarkable aspect of the study is that the second group with the highest level was the group whose mother's educational level is illiterate. Besides, Dilbaz (2019) stated in their research that reader self-perception makes a significant difference in terms of the mother's educational level, but it does not make any difference in terms of father's educational level. Topçu (2005) noted that parents also purchased different books from the textbook for the students as their economic income and education levels increase.

In the fifth sub-problem, secondary school students' mean ranks regarding the differentiation of reading habits in terms of the variable of going to the library were examined. The research findings suggest that there is a significant difference between the mean ranks of students who 
go to the library and the mean ranks of students who do not go to the library in favor of the students who go to the library. Similarly, the mean ranks regarding the differentiation of reading anxiety by the variable of going to the library show that there is a significant difference in favor of the students who go to the library between the mean ranks of students who go to the library and the mean ranks of students who do not go to the library. Darican (2014) stated that going to places such as bookstore and fair is effective in developing a positive perspective on the reading habits of students.

The sixth sub-problem of the research was about whether there is a relationship between reading habits and reading anxiety and frequency of watching television. The results concluded that there is a significant difference in terms of secondary school students' reading habits in favor of the students who watch television for 1 hour every day between students who watch television for 1 hour every day and students who watch television for more than 2 hours every day. Also, there is a significant difference in terms of secondary school students' reading habits in favor of the students who watch television for 2 hours every day between students who watch television for 2 hours every day and students who watch television for more than 2 hours every day. In terms of reading anxiety of secondary school students, there is a significant difference in favor of students who watch television for 1 hour every day between those who watch television for 1 hour every day and those who watch television for 2 hours every day. Yurtbakan (2017) identified that television hinders students from reading. In their study, Deniz (2017) mentioned that technological developments have positive effects as well as serious adverse effects. The research results of Gül (2019) also support this conclusion, noting that students' reading attitude habits and upper cognitive awareness are closely related to their daily television watching time.

\section{Implications}

(1) The deficiencies of materials, tools, and materials thought to be useful for increasing the reading habit, eliminating or decreasing the reading habit should be eliminated, the types and hours of activities should be increased, and the opportunities should be expanded.

(2) The children should be assigned reading exercises frequently, and as a result, it should be ensured to acquire reading habit free from anxiety. They should also have a library of books that they want at home.

(3) Students should be guided to libraries to develop a reading culture, and they should be able to recognize many types of books. Parents should follow the periodicals, and the children should be introduced to different types of reading materials from an early age.

(4) A friendly classroom environment should be arranged so that students do not experience anxiety while reading in the classroom environment. In order for students to be able to read freely in the classroom environment, speaking activities should be prepared to reduce anxiety and increase self-confidence.

\section{Limitations}

This study has several limitations. This study includes only students studying at a secondary 
school and the variable of gender, grade, and educational level of parents. By adding other variables with different types of school or different grade students or other participants with different characteristics, comparative, larger scale, differently designed studies should be conducted using qualitative and quantitative research methods, and the results should be reflected on the field.

\section{Acknowledgements}

This study was produced from the author's master thesis which was conducted at Atatürk University, Institute of Educational Sciences under the guidance of Assistant Professor Siddik Bakir.

\section{References}

Alyılmaz, C. (2010). Problems of teaching Turkish. Turkish Studies, 5(10), 728-749. https://doi.org/10.7827/TurkishStudies.1629

Ataş, M. (2015). The examining reading motivation of primary students in the terms of some variables (Master's Thesis No. 396070, Higher Education Council National Thesis Center). Retrieved from https://tez.yok.gov.tr/UlusalTezMerkezi/giris.jsp

Baki, Y. (2017). The effect of anxiety and attitudes of secondary school students towards reading on their reading habits: A structural equation modeling. Education and Science, 42(191), 371-395. https://doi.org/10.15390/EB.2017.7223

Balc1, A. (2009). A research on elementary 8th grade students' reading habits and interests (Doctoral Dissertation No. 228411, Higher Education Council National Thesis Center). Retrieved from https://tez.yok.gov.tr/UlusalTezMerkezi/giris.jsp

Bamberger, R. (1990). In B. Çapar, (Trans.), Developing reading habits. Ankara: Ministry of Culture Publications.

Biçer, N., Çoban, İ., \& Bakır, S. (2014). The problems faced by the foreign students learning Turkish: Atatürk University case. The Journal of International Social Research, 7(29), 125-135.

Çeliktürk, Z., \& Yamaç, A. (2015). Development of the reading anxiety scale for elementary and middle school students: Validity and reliability study. Elementary Education Online, 14(1), 97-07. https://doi.org/10.17051/io.2015.03320

Çetinkaya, S. Ç. (2004). The reading habits of 8th class primary school students in Afyon centre. (Master's Thesis, Kocatepe University Institute of Educational Science, Afyon). Retrieved from https://tez.yok.gov.tr/UlusalTezMerkezi/giris.jsp

Darican, A. M. (2014). The research of the reading habits of 4th grade primary school students (Master's Thesis No. 359943, Higher Education Council National Thesis Center). Retrieved from https://tez.yok.gov.tr/UlusalTezMerkezi/giris.jsp

Davarc1, N. (2013). An investigation on the evaluation of the relationship between the reading habits of 8 th grade elementary school students and their the habits of 
computer-internet usage (Master's Thesis No. 369338, Higher Education Council National Thesis Center). Retrieved from https://tez.yok.gov.tr/UlusalTezMerkezi/giris.jsp

Deniz, A. (2017). Opinions of Turkish teachers on the development of reading habits of secondary school students (Master's Thesis No. 486355, Higher Education Council National Thesis Center). Retrieved from https://tez.yok.gov.tr/UlusalTezMerkezi/giris.jsp

Dilbaz, G. H. (2019). The evaluation of reading attitude and reader self-perception of middle school students by various factors (Master's Thesis No. 563046, Higher Education Council National Thesis Center). Retrieved from https://tez.yok.gov.tr/UlusalTezMerkezi/giris.jsp

Duran, T. (2018). An investigation of writing tendencies and reading habits of primary school students in terms of various variabilities (Master's Thesis No. 543928, Higher Education Council National Thesis Center). Retrieved from https://tez.yok.gov.tr/UlusalTezMerkezi/ giris.jsp

Er, O., Biçer, N., \& Bozkırlı, K. Ç. (2012). Evaluation of problems encountered in Turkish teaching for foreigners in terms of related literature. International Journal of Turkish Literature Culture Education, 1(2), 51-69. https://doi.org/10.7884/teke.51

Grills-Taquechel, A. E., Fletcher, J. M., Vaughn, S. R., \& Stuebing, K. K. (2012). Anxiety and reading difficulties in early elementary school: evidence for unidirectional-or bi-directional relations? Child Psychiatry \& Human Development, 43(1), 35-47. https://doi.org/10.1007/s10578-011-0246-1

Gül, B. (2019). Relationship between reading attitudes and habits and metacognitive awareness level of secondary school students (Master's Thesis No. 548744, Higher Education Council National Thesis Center). Retrieved from https://tez.yok.gov.tr/UlusalTez Merkezi/giris.jsp

Güngör, E. (2009). An investigation on the relationship between the reading habits of 5th grade elementary school students and their Turkish lesson academic achievement (Master's Thesis No. 241470, Higher Education Council National Thesis Center). Retrieved from https://tez.yok.gov.tr/UlusalTezMerkezi/giris.jsp

Gürcan, H. İ. (1996). A recommendation of a model on the basis of Turkey conditions for problems of cultural communication and technology of reading habits and book publishing (Doctoral Thesis No. 118331, Higher Education Council National Thesis Center). Retrieved from https://tez.yok.gov.tr/UlusalTezMerkezi/giris.jsp

Harris, A. J., \& Sipay, E. R. (1990). How to increase reading ability: A guide to developmental and remedial methods (9th ed.). London: Longman.

Karademir, M. (2018). What is the level of reading habits of 4th grade students of elementary school? (Master's Thesis No. 550568, Higher Education Council National Thesis Center). Retrieved from https://tez.yok.gov.tr/UlusalTezMerkezi/giris.jsp

Karahan, B. Ü. (2015). The relation of 5th and 6th grade students' attitude and motivation toward reading to reading comrehension skills (Doctoral Thesis No. 389161, Higher 
Education Council National Thesis Center). Retrieved from https://tez.yok.gov.tr/UlusalTez Merkezi/giris.jsp

Karasar, N. (2013). Scientific research method (25th ed.). Ankara: Nobel Publishing.

Keleş, Ö. (2006). The investigation of fourth and fifth grades of primary school students' reading habits (Master's Thesis No. 187641, Higher Education Council National Thesis Center). Retrieved from https://tez.yok.gov.tr/UlusalTezMerkezi/giris.jsp

Küçükoğlu, A., Taşgın, A., \& Saadnie, A. (2014). A comparative research upon views of Turkish and Iranian teacher candidates about teaching profession. Atatürk University Journal of Turkish Studies Institute, 51, 395-416.

MacIntyre, P. D., \& Gardner, R. C. (1991). Investigating language class anxiety using the focused essay technique. The Modern Language Journal, 75(3), 296-304. https://doi.org/ 10.1111/j.1540-4781.1991.tb05358.x

Mert, O., Alyılmaz, S., Bay, E., \& Akbaba, S. (2009). A study on the comprehention level of the candidate lecturers regarding the social values on the Orkhun Inscriptions. Journal of International Social Studies, 2(9), 279-287.

Ministry of Education. (2006). Primary school Turkish lesson (6, 7, 8.) grade teaching program. Ankara: Board of Education and Discipline.

Mori, S. (2004). Significant motivational predictors of the amount of reading by EFL learners in Japan. RELC Journal, 35(1), 63-81. https://doi.org/10.1177/003368820403500106

Rains, N. N. (1993). A Study of attitudes toward reading of western Kansas students in grades one through six in a selected school (Master's Theses). Retrieved from https://scholars.fhsu.edu/theses/2420

Schwabe, F., McElvany, N., \& Trendtel, M. (2015). The school age gender gap in reading achievement: Examining the influences of item format and intrinsic reading motivation. Reading Research Quarterly, 50(2), 219-232. https://doi.org/10.1002/rrq.92

Soysal, P. I. (2014). The factors that affects to the secondary school students reading comprehension levels (Master's Thesis No. 396070, Higher Education Council National Thesis Center). Retrieved from https://tez.yok.gov.tr/UlusalTezMerkezi/giris.jsp

Tanju, E. H. (2010). An overview of the habit of reading books in children. Family and Society, 11(6), 30-39.

Tekin, H. (1980). Teaching Turkish in our schools in terms of improving the comprehension skills with written reading comprehension. Ankara: Mars Printing.

Tok, M., Küçük, B., \& Kırmacı, Ö. (2015). Development of reading anxiety scale for secondary school students: validity and reliability study. Theory and Practice in Education, 11(2), 694-16.

Topçu, Y. E. (2005). Reading habits of the secondary school students (6, 7, 8. grades) 


\section{Macrothink}

(sample of Kayseri) (Master's Thesis No. 159277, Higher Education Council National Thesis Center). Retrieved from https://tez.yok.gov.tr/UlusalTezMerkezi/giris.jsp

Worrell, F. C., Roth, D. A., \& Gabelko, N. H. (2006). Elementary reading attitude survey (ERAS) scores in academically talented students. Roeper Review, 29(2), 119-124. https://doi.org/10.1080/02783190709554395

Yamaç, A., \& Sezgin, Z. Ç. (2018). Relationships among fourth graders' reading anxiety, reading fluency, reading motivation, and reading comprehension. Education and Science, 43(194), 225-243. https://doi.org/10.15390/EB.2018.7555

Y1ldı, M., \& Ceyhan, S. (2016). The investigation of 4th grade primary school students' reading and writing anxieties in terms of various variables. Turkish Studies, 11(2), 1301-1316. https://doi.org/10.7827/TurkishStudies.9370

Yurtbakan, E. (2017). A descript of reading habits of primary school 4th grade students (Master's Thesis No.472015, Higher Education Council National Thesis Center). Retrieved from https://tez.yok.gov.tr/UlusalTezMerkezi/giris.jsp

\section{Copyright Disclaimer}

Copyright for this article is retained by the author(s), with first publication rights granted to the journal.

This is an open-access article distributed under the terms and conditions of the Creative Commons Attribution license (http://creativecommons.org/licenses/by/3.0/). 